\title{
Identifying Controls on Water Chemistry of Tropical Cloud Forest Catchments: Combining Descriptive Approaches and Multivariate Analysis
}

\author{
Amelie Bücker • Patricio Crespo • Hans-Georg Frede • \\ Kellie Vaché $\cdot$ Felipe Cisneros $\cdot$ Lutz Breuer
}

Received: 8 June 2009/Accepted: 1 October 2009/Published online: 27 October 2009

(C) Springer Science+Business Media B.V. 2009

\begin{abstract}
We investigated controls on the water chemistry of a South Ecuadorian cloud forest catchment which is partly pristine, and partly converted to extensive pasture. From April 2007 to May 2008 water samples were taken weekly to biweekly at nine different subcatchments, and were screened for differences in electric conductivity, $\mathrm{pH}$, anion, as well as element composition. A principal component analysis was conducted to reduce dimensionality of the data set and define major factors explaining variation in the data. Three main factors were isolated by a subset of 10 elements $\left(\mathrm{Ca}^{2+}, \mathrm{Ce}, \mathrm{Gd}, \mathrm{K}^{+}, \mathrm{Mg}^{2+}\right.$, $\mathrm{Na}^{+}, \mathrm{Nd}, \mathrm{Rb}, \mathrm{Sr}, \mathrm{Y}$ ), explaining around $90 \%$ of the data variation. Land-use was the major factor controlling and changing water chemistry of the subcatchments. A second factor was associated with the concentration of rare earth elements in water, presumably highlighting other anthropogenic influences such as gravel excavation or road construction. Around $12 \%$ of the variation was explained by the third component, which was defined by the occurrence of $\mathrm{Rb}$ and $\mathrm{K}$ and represents the influence of vegetation dynamics on element accumulation and wash-out. Comparison of base- and fast flow concentrations led to the assumption that a significant portion of soil water from around $30 \mathrm{~cm}$ depth contributes to storm flow, as revealed by increased rare earth element concentrations in fast flow samples. Our findings demonstrate the utility of multi-tracer principal component analysis to study tropical headwater streams, and emphasize the need for effective land management in cloud forest catchments.
\end{abstract}

Keywords Ecuador - Tropical cloud forest - Principal component analysis · Water quality $\cdot$ Land-use change $\cdot$ Rare earth elements

\footnotetext{
A. Bücker · P. Crespo · H.-G. Frede · K. Vaché · L. Breuer ( $\square)$

Institute for Landscape Ecology and Resources Management, Justus-Liebig University Giessen, Heinrich-Buff Ring 26, 35392 Giessen, Germany

e-mail: lutz.breuer@umwelt.uni-giessen.de

P. Crespo

Universidad de Cuenca, Quinta de Balzain, Av. Victor Manuel Albornoz, Cuenca, Ecuador

F. Cisneros

Programa para el Manejo del Agua y el Suelo (PROMAS), Universidad de Cuenca, Av. 12 de Abril s/n Cuidadela Universitaria, Cuenca, Ecuador
} 


\section{Introduction}

Tropical cloud forests are one of the most species rich ecosystems in the world, but also one of the most endangered. In contrast to lowland rain forests, a main characteristic of cloud forests is the interception of cloud moisture, which makes them unique in their watershed quality and quantity (Doumenge et al. 1995). The scarce knowledge of the functioning of these fragile systems, and the changes that result from deforestation, may hinder effective environmental management (Feddema et al. 2005). The conversion of cloud forest to pasture or crop land and the fast degradation of these ecological units thereafter is one of the big threats that tropical regions are facing nowadays (Günther et al. 2007). It is widely recognized that small-scale climate regimes, soil chemistry and hydrology, among others, are influenced by the loss of forest cover (Ataroff and Rada 2000; Neill et al. 2006), but the degree of this influence is poorly known. Both the pristine and the transformed state of the ecosystem, including inputs and outputs, should be investigated to detect changes in physical and chemical parameters of tropical forest catchments. Just as important as detecting changes is the question of why these changes occur, which is an issue of alteration in soil processes and flow paths (Burt and Pinay 2005).

One of the big unknowns of tropical cloud forest systems still is the fate of water. Which paths does it take? How is its chemistry influenced and changed before it leaves the system? How does deforestation alter the course of the water and its associated chemistry? What are the major drivers of water quality? These questions can be answered not only by subsurface flow path investigations but also via spatially distributed water quality surveys. Subsurface flow paths (infiltration, groundwater flow) and surface water quality (subcatchments, source areas etc.) are intimately connected in a catchment (Soulsby et al. 2007; Tetzlaff and Soulsby 2007b). In remote areas though, most studies focus on only one of these fields, probably mostly due to limited time and resources.

Subsurface flow paths have been identified in the small scale by employing artificial dye tracers and excavating soil profiles after tracer irrigation (Albrecht et al. 2003; McLeod et al. 1998; Vanderborght et al. 2002). For a larger scale, natural tracer concentrations $\left(\mathrm{Cl}^{-}, \mathrm{SiO}_{2}\right)$ and isotopes $\left(\mathrm{H}^{3}, \mathrm{O}^{18}, \mathrm{~N}^{15}\right)$ have been monitored to derive flow path understanding and generation of storm hydrographs (Rice and Hornberger 1998; Rodgers et al. 2005; Soulsby et al. 2006; Tetzlaff and Soulsby 2007a; Uhlenbrook et al. 2002). In tropical regions, subsurface flow path studies clearly dominate over surface water analyses (Elsenbeer et al. 1994; Elsenbeer and Lack 1996; Elsenbeer and Vertessy 2000; Goller et al. 2005; Schellekens et al. 2004; Wilcke et al. 2001).

Surface water (source area, water quality) investigations are mostly conducted by sampling different subcatchments, and either analyze bulk parameters ( $\mathrm{pH}$, conductivity, alkalinity) or ion and element concentrations to spatially and temporally quantify all water quality aspects of a catchment (Bernal and Sabater 2008; Clow et al. 1996; Simeonov et al. 2003). Often paired catchment approaches are used to investigate alterations in flow chemistry with land-use change (Neill et al. 2001; Ramos-Escobedo and Vázquez 2001). In the tropics mainly small watersheds were used for water quality studies, and have, according to Neill et al. (2006), played a large role in the understanding of catchment functioning. Almost all studies, however, have in common that they focus on the fate of some few nutrients or elements, such as sulfate, carbon or nitrate, and nitrogen, respectively, or on bulk parameters like alkalinity and conductivity (Poor and McDonnell 2007; 
Worrall et al. 2003). In areas with few site data, and even more so in tropical headwater streams with low nutrient concentrations, it is questionable whether such an approach is sufficient because concentration differences are often very small in standard parameters. To overcome this problem, multi-tracer investigations represent a feasible option for improving the understanding of ungauged headwater basin processes. With the fast improvement in analytical techniques, trace elements such as, e.g., rare earth elements (REEs) have become popular as environmental tracers, at least in geochemical studies (Bwire Ojiambo et al. 2003; Chung et al. 2008; Viers and Wasserburg 2004). REEs encompass all elements belonging to the Lanthanides (periodic table elements 57-71), plus scandium (element 21), and yttrium (element 39). Due to their ubiquity in the earth's crust they represent good tracers for weathering rates and for geological and pedological processes (Hannigan and Sholkovitz 2001; Hu et al. 2006).

Hydro-chemical studies that include a variety of sampling sites and analytes inevitably result in large amounts of data. The variation in the data reflects different chemical behavior, different spatio-temporal sources, as well as different hydrologic conditions, making an interpretation of the results difficult. To derive general trends, the complexity of the data sets can be reduced to a few, more easily interpretable, components. Principal component analysis (PCA) is a statistical tool which is typically employed to reduce the number of dimensions in hydro-chemical data (Christophersen and Hooper 1992). In a PCA, the variation in data is projected on new, abstract orthogonal principal components (eigenvectors), with each principal component, or factor, describing a different source of variation for the data set. Each factor thus is derived from a set of correlated elements, which are influenced by the same underlying processes (flow paths) or environmental parameters (e.g., geology, anthropogenic disturbance, season). This correlation among elements which is specific for every factor enables the scientist to draw conclusions on the sources of this "collective" variation.

Here we use principal component analysis on water samples of a tropical montane cloud forest catchment. We investigate a set of over 30 elements and nutrients, which can be analyzed by standard laboratory methods. Our methodology is based on a paired catchment approach, with forested and deforested sites located in the same $75 \mathrm{~km}^{2}$ cloud forest catchment. Both sites are geologically as well as topographically comparable (Makeschin et al. 2008).

Our objectives were to (1) generally describe the spatial and temporal variation in water quality of a mesoscale tropical cloud forest catchment using qualitative approaches and PCA, and to (2) evaluate if differences in water chemistry of subcatchments can be attributed to land-use and -management practices.

This leads us to the hypotheses that

(1) in remote, ungauged basins, the analysis of hydro-chemical characteristics of surface and subsurface flows can help to elucidate the sources and flow-paths of water,

(2) land-use practices are the predominant controls on water chemistry in tropical montane watersheds,

(3) in headwater streams, differences in water chemistry are attenuated at high flows due to rain dilution processes,

(4) water parameters commonly taken as indicators of water chemistry change (e.g., $\mathrm{pH}$, $\mathrm{EC}, \mathrm{SO}_{4}{ }^{2-}, \mathrm{Ca}^{2+}$ ) are not sufficient to explain controls on water chemistry in the ion poor waters of tropical cloud forest catchments. Rare earth elements can be of use in these areas. 


\section{Materials and Methods}

\subsection{Site Description}

The study catchment is situated at $03^{\circ} 58^{\prime} \mathrm{S}$ and $79^{\circ} 04^{\prime} \mathrm{W}$ in the south of Ecuador $(1,800$ $3,140 \mathrm{~m}$ a.s.1.). The San Francisco catchment drains a $75.3 \mathrm{~km}^{2}$ area in the Cordillera Real, on the eastern slope of the Andes facing the Amazon basin. A deeply incised valley divides the watershed into a northern and a southern sub-area. In the north, the natural forest has been replaced by extensive pastures (Setaria sphacelata, Schumach.) (Werner et al. 2005), with some pine plantations being spread in between. After some years of use, pastures are mostly overgrown by ferns (Pteridium aquilinum, L.) and thereafter abandoned. The only road in the study area also draws its course along the northern slope. It connects the province capitals Loja and Zamora. Taking advantage of this road, two creeks situated in the northwest (Quebrada Zurita, Quebrada Navidades) are used for gravel excavation (see Fig. 1).

The southern portion of the basin exists within the Podocarpus National Park and is covered with an almost pristine montane cloud forest with canopy heights rarely exceeding $20 \mathrm{~m}$. Dominant plant species are of the families Lauraceae, Euphorbiaceae, Melastomataceae, and Rubiaceae (Homeier et al. 2002). The highest crest of the study region, the so called "Antenas" at 3,140 m a.s.l., is also located in the southern part. All crest regions are predominantly covered by a neotropical alpine grass- and shrub land (páramo) and an evergreen elfin forest, both of which are adapted to higher wind speed, lower temperatures, and lower nutrient availability (Beck et al. 2008). Numerous landslides, naturally opening space for secondary forest growth, characterize the landscape. One of the factors favoring landslides most probably is the steep topography of the San Francisco Valley. Around $76 \%$ of all slopes are steeper than $25^{\circ}$, with $19 \%$ hereof even steeper than $40^{\circ}$ (Beck et al. 2008).

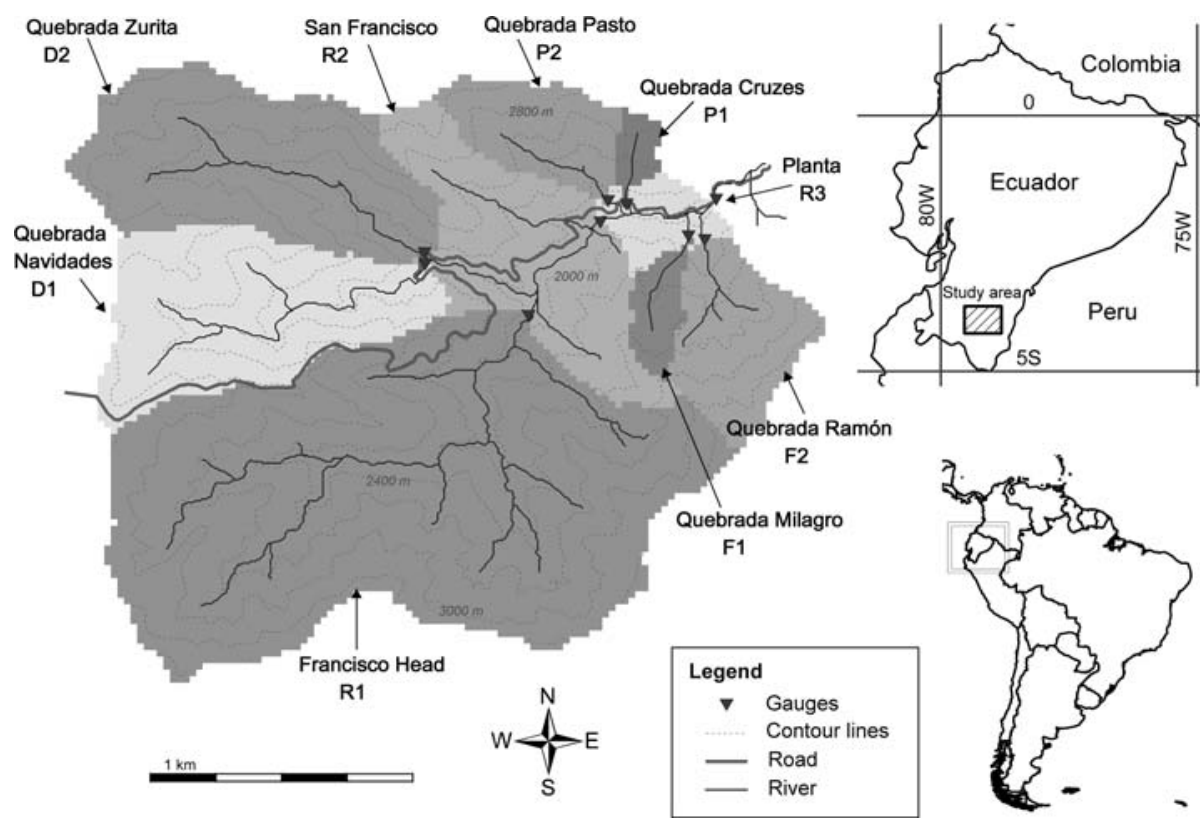

Fig. 1 Study catchment and subcatchments with sampling points 
The catchment's climate regime generally originates from the east and results in three distinct local climate zones (Bendix et al. 2008). The lower part of the study area at around $2,000 \mathrm{~m}$ exhibits a mean annual rainfall of $2,050 \mathrm{~mm}$, low average wind speeds and relatively little cloud cover. The uppermost part, however, shows a dramatic increase in precipitation amounts (around 4,400 $\mathrm{mm}$ at 3,140 $\mathrm{m}$ a.s.1) as well as wind speed and cloud cover (data from 1998 to 2004, Rollenbeck 2006; Bendix et al. 2008). Lastly, a transition zone situated in moderate altitudes closes the link between these extremes. These altitudinal differences in climatic regime are true for the whole catchment area. In general, the region is clearly marked by two seasons, with the rainy season peaking around May and June and the dry season between October and December.

Geologically, the research area belongs to the Chiguinda Unit of the Zamora Series, which is mainly composed of paleozoic metamorphic rocks like semipelites, phyllites, and quartzites (Litherland et al. 1994). Soils in the study area range from Cambisols (below $2,100 \mathrm{~m}$ ) with a moderate organic layer, to Histosols (above 2,100 m) with an increasing organic layer thickness (Wilcke et al. 2008). In the organic layer, a decrease in macronutrient concentration $\left(\mathrm{N}, \mathrm{P}, \mathrm{K}, \mathrm{Ca}^{2+}, \mathrm{Mg}^{2+}\right.$ ) with altitude is countered by the increasing depth of the organic layer, therefore nutrient storages per $\mathrm{m}^{2}$ are similar along altitudinal gradients (Wilcke et al. 2008). In general, nutrient concentrations vary greatly between the organic layer and the A horizon, with $\mathrm{C}, \mathrm{Ca}^{2+}, \mathrm{Mg}^{2+}, \mathrm{N}$, and $\mathrm{P}$ concentrations being higher in the organic layer, and $\mathrm{K}^{+}$being lower (Wilcke et al. 2008). Most studies investigating soil properties in the area concur that small-scale heterogeneity is predominant (Huwe et al. 2008) in part probably due to the frequent landslides along the steep slopes of the valley.

\subsection{Sampling Design}

We used a nested sampling approach, with a total of ten sampling sites in nine subcatchments (see Fig. 1, Table 1). The sites were chosen according to land-use characteristics and accessibility of the area, the latter one being a highly restricting factor in the steep and mostly impenetrable catchment. We thus located six sampling stations in different tributaries, i.e., two in forested (F1, F2), two in pasture creeks (P1, P2), and two in anthropogenically disturbed sub-catchments (D1, D2). Additionally we sampled three sites in the main river (R1, R2, R3). The forest creek F2 was sampled in two locations. Just

Table 1 General information on the sampling sites

\begin{tabular}{llllll}
\hline No. & (Land-) use & Station name & Code & Size $\left(\mathrm{km}^{2}\right)$ & Location \\
\hline 1 & Mixed, disturbed & Quebrada Navidades & $\mathrm{D} 1$ & 10.15 & Western slope \\
2 & Mixed, disturbed & Quebrada Zurita & $\mathrm{D} 2$ & 11.38 & North-western slope \\
3 & Forest & Quebrada Milagro & F1 & 1.27 & Southern slope \\
4 & Forest & Quebrada Ramón (a) & F2a & 4.46 & Southern slope \\
5 & Forest & Quebrada Ramón (b) & F2b & 4.49 & Southern slope \\
6 & Extensive pasture & Quebrada Cruzes & P1 & 0.69 & Northern slope \\
7 & Extensive pasture & Quebrada Pasto & P2 & 3.45 & Northern slope \\
8 & Forest & Francisco Head & R1 & 35.01 & Main river \\
9 & Mixed & San Francisco & R2 & 65.41 & Main river \\
10 & Mixed & Planta & R3 & 75.28 & Main river \\
\hline
\end{tabular}


before F2 flows into the main river, a small channel diverts creek water to a power plant downriver. We sampled before (F2a) and after (F2b) the channel diversion. After the channel diversion a spring emerging from a rock fracture enters the creek $\left(F_{\text {well }}\right)$. F2b was situated after the mixing of well water with the remaining creek water.

For principal component analysis we also included measurements of three wells. One situated in the $\mathrm{P} 1$ catchment $\left(\mathrm{P}_{\text {well }}\right)$, one in the $\mathrm{F} 2$ catchment $\left(\mathrm{F}_{\text {well }}\right)$, and one entering the main river next to the $\mathrm{R} 2$ sampling station $\left(\mathrm{R}_{\mathrm{well}}\right)$. Rain (labeled 'Rain' in the PCA) was sampled on an event basis, and surface water from 2,750 m altitude was taken during nonprecipitation periods in pristine (sub-)páramo vegetation (labeled 'Paramo' in the PCA), reflecting water sources with a higher amount of fog water.

Water grab samples were taken at all stations between April 2007 and May 2008 at weekly to biweekly intervals. For each sample, two aliquots were taken, one for element analysis, collected in an acid washed PE bottle. The second sample was collected in a PE bottle rinsed with deionized water for the analysis of anions $\left(\mathrm{Cl}^{-}, \mathrm{NO}_{3}{ }^{-}, \mathrm{NO}_{2}{ }^{-}, \mathrm{PO}_{4}{ }^{3-}\right.$, and $\mathrm{SO}_{4}{ }^{2-}$ ). Water samples were filtered through $0.45 \mu \mathrm{m}$ polypropylene membrane filters (Whatman Puradisc 25PP, Whatman Inc.) directly in the field.

Within three hours after collection, element samples were acidified to a $\mathrm{pH}<2$ (using nitric acid) in the field-lab and then kept cool until analyzed. Element concentrations were determined via inductively coupled plasma-mass spectrometry (ICP-MS, Agilent 7500ce, Agilent Technologies). The Agilent 7500ce is able to perform ultra-trace measurements of complex unknown samples and therefore allowed us to semi-quantitatively analyze a variety of elements over a wide concentration range. The quality of the results of the ICPMS measurements was controlled by certified reference material (NIST 1643e and NRCSLRS4) and via additional internal calibration standards. The following elements were considered (in alphabetical order): $\mathrm{Al}, \mathrm{As}, \mathrm{Ba}, \mathrm{Ca}^{2+}, \mathrm{Ce}, \mathrm{Cr}, \mathrm{Cu}, \mathrm{Dy}, \mathrm{Er}, \mathrm{Fe}, \mathrm{Fl}, \mathrm{Gd}, \mathrm{K}^{+}$, $\mathrm{La}, \mathrm{Li}, \mathrm{Mg}^{2+}, \mathrm{Mn}, \mathrm{Na}^{+}, \mathrm{Nd}, \mathrm{Ni}, \mathrm{Pb}, \mathrm{Pr}, \mathrm{Rb}, \mathrm{Sm}, \mathrm{Sr}, \mathrm{U}, \mathrm{V}, \mathrm{Y}, \mathrm{Yb}$, and $\mathrm{Zn}$. Element concentrations of $\mathrm{Co}, \mathrm{Cd}, \mathrm{Eu}, \mathrm{Tb}, \mathrm{Ho}, \mathrm{Lu}$, and $\mathrm{Tm}$ were below detection limit.

For $\mathrm{Cl}^{-}, \mathrm{NO}_{3}{ }^{-}, \mathrm{NO}_{2}{ }^{-}, \mathrm{PO}_{4}{ }^{3-}$, and $\mathrm{SO}_{4}{ }^{2-}$ samples were frozen within three hours after collection until they were analyzed by ion chromatography (DX-120, Dionex Corporation). Every sample value represents the mean of two consecutive measurements.

The $\mathrm{pH}$ and electric conductivity $(\mu \mathrm{S} / \mathrm{cm})$ were measured directly in the field $(\mathrm{pH} / \mathrm{Cond}$ 340i, WTW, Weilheim, Germany). Due to the ion poor water, the pH-electrode Sen Tix HW was especially chosen for these low-conductivity measurements.

Silicate could not be analyzed by our standard methods and was thus omitted in the following analysis. However, some measurements were conducted using rapid tests (Merck, Microquant $0.5-15.0 \mathrm{mg} / 1 \mathrm{SiO}_{2}$ ) with a precision of $\pm 0.5 \mathrm{mg} / \mathrm{l} \mathrm{SiO}_{2}$ and this data were used to later on discuss the origin of well water.

\subsection{Data Analysis}

To be able to differentiate between variation due to land-use and hydrologic regime, we classified water samples into two flow conditions, i.e., baseflow and fast flow condition. Baseflow samples were defined as samples taken at hydrologic conditions with at least $70 \%$ baseflow (Fig. 2). Among the many methods to differentiate between base- and fast flow, we decided to use a numerical filter because of the ease of use and good reproducibility. Baseflow contribution was thus derived by the recursive digital baseflow filter implemented in the WETSPRO tool (Willems 2009). WETSPRO applies a filter for exponential recessions proposed by Chapman (1991). All samples not applying to baseflow conditions were classified as "fast flow samples." Thus, between 10 and 13 baseflow and 16 and 24 

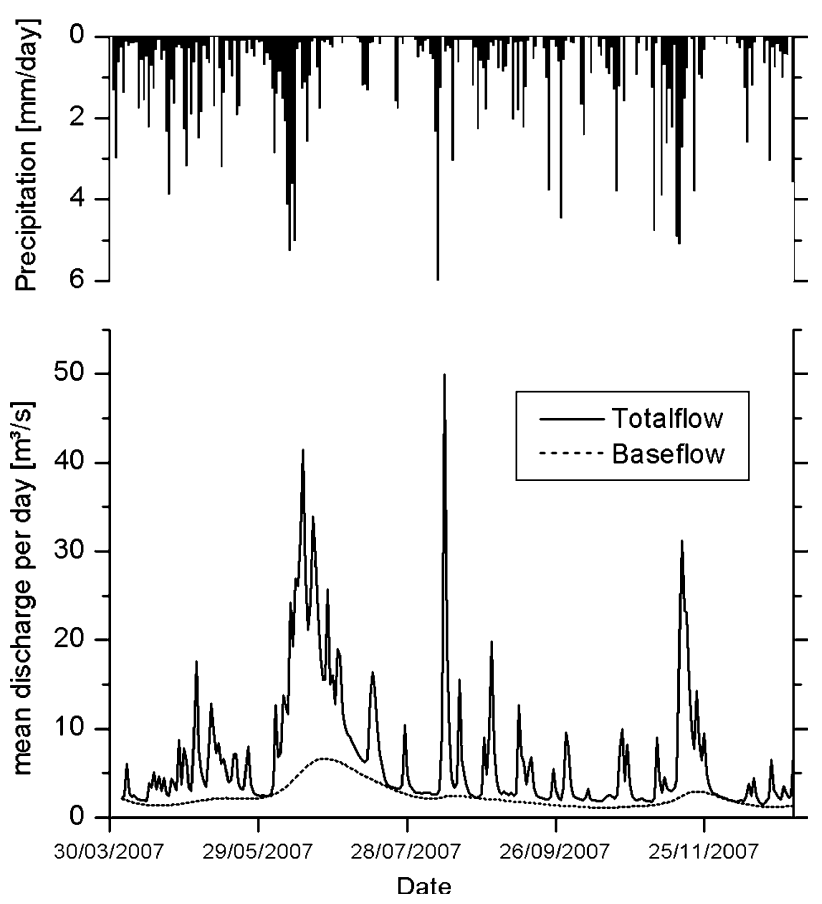

Fig. 2 Hydrograph separation and daily precipitation values (gauge at 1,980 m) for the outlet, PL

fast flow samples were available for each station. At one pasture creek station (P1) though, we only had 6 baseflow and 10 fast flow samples available for analysis because this sampling station was not set up until September 2007.

For statistical analysis, means (and standard deviation) of element baseflow concentration at all sampling stations were calculated. A comparison of means was conducted using an analysis of variance (ANOVA) and $\alpha=0.05$. If significant differences were apparent, we applied Scheffé's multiple pair-wise comparison of means to extract differences among sampling stations for every investigated parameter (Scheffé's PostHoc Test, $\alpha=0.05$ ). The results of this comparison are summarized in Sect. 3.1.

In a second step, for principal component analysis (PCA), all water chemistry data were converted to molar concentration units and standardized (i.e., centered by subtracting the arithmetic mean, and divided by the respective standard deviation) according to Hooper (2003).

PCA was developed using the whole set of elements for baseflow samples, only excluding the elements which did not reveal any spatial difference in the ANOVA. Then, subsets of ten elements were tested for factor loadings and variation explained. The set having highest loadings and best explaining the variation in the data was chosen for further analysis. To account for the heterogeneity in variances, the PCA analysis was based on a correlation matrix. All factors explaining 5\% or more of the variation in the data were retained.

To clarify differences in base- and fast flow concentration for the elements used in the PCA, we also applied an ANOVA $(\alpha=0.05)$ comparing mean concentrations of the two flow conditions. All statistics were executed with the STATISTICA Software (StatSoft ${ }^{\circledR}$ ), Version 6.0. 


\section{Results and Discussion}

\subsection{Descriptive Spatial Analysis of Element Concentration}

As expected for headwater streams, concentrations of all elements and nutrients were very low. The chemical constituents of river water at baseflow condition are summarized in Tables 2 and 3 for all stations. Major cations were $\mathrm{Na}^{+}, \mathrm{Ca}^{2+}, \mathrm{Mg}^{2+}$, and $\mathrm{K}^{+}$, major anions $\mathrm{Cl}^{-}, \mathrm{NO}_{3}{ }^{-}$, and $\mathrm{SO}_{4}{ }^{2-}$. Neither $\mathrm{NO}_{2}{ }^{-}$nor $\mathrm{PO}_{4}{ }^{3-}$ was detected. This was probably due to a relatively high detection limit of $0.5 \mathrm{mg} / \mathrm{l}$ for phosphate and $0.1 \mathrm{mg} / \mathrm{l}$ for nitrite. Mean ion concentrations generally were low, as reflected in the electric conductivity, which ranged from 5.9 to $31.9 \mu \mathrm{S} / \mathrm{cm}$. The concentrations of most parameters varied much more strongly in the fast flow samples compared to the baseflow samples (compare Figs. 3 and 4).

Despite these low concentrations, significant differences between land-uses were apparent. Forest creeks F1 and F2a were clearly separated from the other catchments by having the lowest $\mathrm{pH}$ values, and low $\mathrm{NO}_{3}{ }^{-}, \mathrm{SO}_{4}{ }^{2-}, \mathrm{Na}^{+}, \mathrm{Mg}^{2+}, \mathrm{Ca}^{2+}, \mathrm{K}^{+}, \mathrm{Sr}$, and As concentrations. Both sites in forest creek F2 possessed significantly higher Rb concentrations, but Rb was also elevated in F1. Site F2b (after channel diversion and well water input) showed highest $\mathrm{NO}_{3}{ }^{-}$concentrations of all streams, whereas $\mathrm{NO}_{3}{ }^{-}$concentration at the outlet was similar to forest creeks $\mathrm{F} 1$ and $\mathrm{F} 2 \mathrm{a} . \mathrm{SO}_{4}{ }^{2-}$ concentration in the uppermost river station R1 was comparable to the values found for F1 and F2a.

Pasture streams showed significantly elevated $\mathrm{Na}^{+}, \mathrm{Mg}^{2+}$, and $\mathrm{Li}$ values, with $\mathrm{Na}^{+}$ being about twice as high as in the other sites. Both disturbed catchments (D1, D2) had significantly higher $\mathrm{SO}_{4}{ }^{2-}$ values and D1 exhibited higher concentrations in Mn, Dy, Er, $\mathrm{Gd}, \mathrm{La}, \mathrm{Nd}, \mathrm{Pr}, \mathrm{Sm}$, and $\mathrm{Y}$, the latter eight elements all belonging to the rare earth elements. No spatial variation was found for the following ten elements: $\mathrm{Al}, \mathrm{Cl}^{-}, \mathrm{Cr}, \mathrm{Cu}$, $\mathrm{Fe}, \mathrm{Ni}, \mathrm{Pb}, \mathrm{U}, \mathrm{Yb}$, and $\mathrm{Zn}$.

Compared to other tropical headwater catchments our study area exhibited noticeably low element concentrations (see Table 5). In montane watersheds of Puerto Rico, e.g., McDowell and Asbury (1994) report comparable values in $\mathrm{K}^{+}$but higher concentrations in $\mathrm{Na}^{+}, \mathrm{Ca}^{2+}, \mathrm{Mg}^{2+}, \mathrm{Cl}^{-}$, and $\mathrm{SO}_{4}{ }^{2-}$. The same is true for a study in a volcanic headwater stream in Mexico, where Ramos-Escobedo and Vázquez (2001) encountered higher values of all cations and anions except $\mathrm{SO}_{4}{ }^{2-}$. This difference to other headwater streams can only be a consequence either of less nutrient input into the catchment via the atmosphere, or of a more effective nutrient retention by the dense forest vegetation and soil.

Chloride concentrations at all sampling stations also were low compared to other tropical headwater catchments (McDowell and Asbury 1994), probably due to the Andes acting as a natural barrier for atmospheric inputs from the coast and climate regimes mostly coming from the east. The overall median molar ratio of $\mathrm{Na}: \mathrm{Cl}$ in the water samples was 3.1 for baseflow and 2.4 for fast flow, which differs considerably from the maritime (precipitation) ratio of 0.85 . Sea spray seems therefore not to play a major role for the input of elements into the watershed, at least during the predominant easterly weather regimes (Boy and Wilcke 2008).

Seasonal changes in concentrations of solutes were only observed in $\mathrm{NO}_{3}{ }^{-}$, where higher concentrations were found in the southern hemisphere winter. No other parameter exhibited a seasonal change during our study period. We therefore did not distinguish between seasons in the following analysis. The question on the possible causes of the observed nitrate seasonality also is not in the scope of this study and will therefore remain unanswered here. 


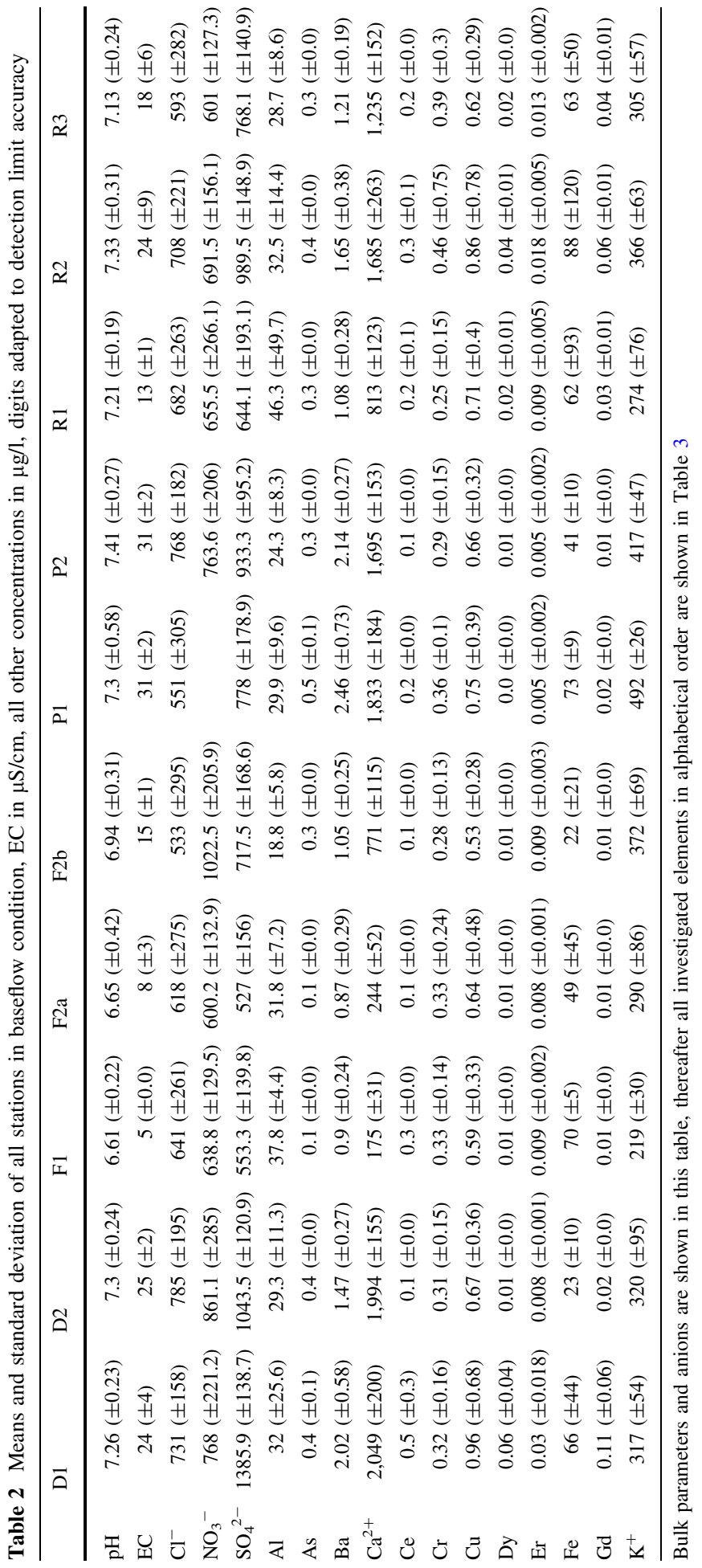




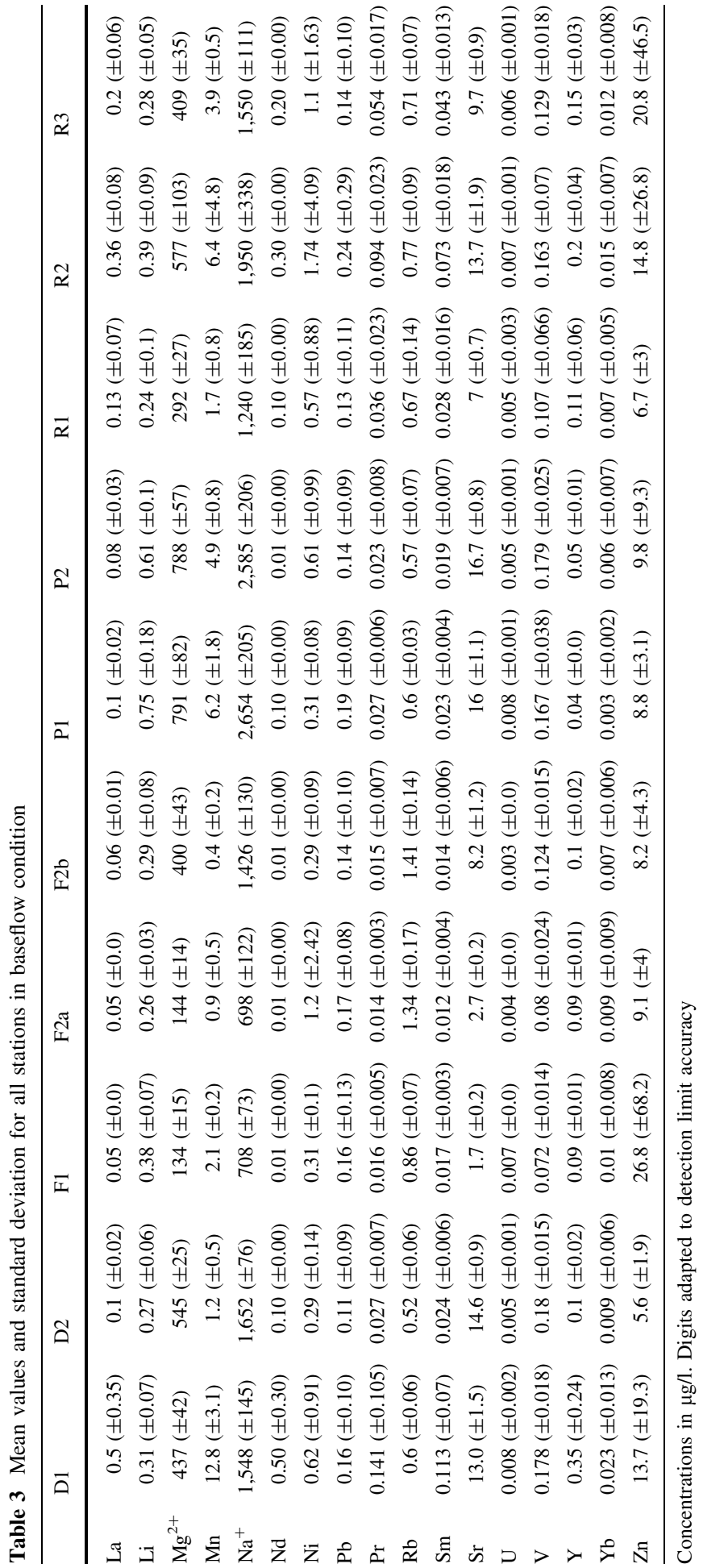


Fig. 3 Boxplot comparison of surface waters at baseflow condition for the ten elements selected for principal component analysis; concentration unit is $\mu \mathrm{g} / \mathrm{l}$ for all elements; for forest creek F2 only the sampling station before channel diversion (F2a) is shown; for better comparison concentration ranges are the same as in Fig. 4
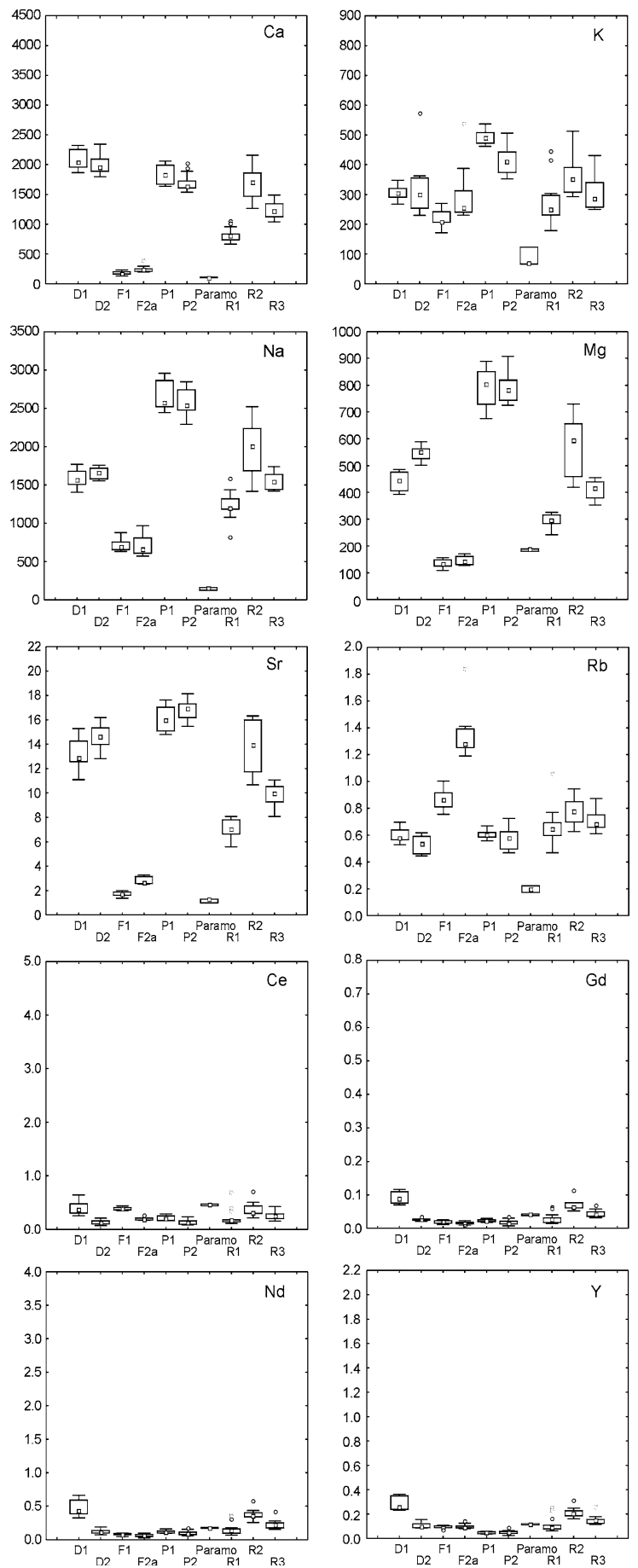
Fig. 4 Boxplot comparison of surface waters at fast flow condition for the ten elements selected for principal component analysis; concentration unit is $\mu \mathrm{g} / \mathrm{l}$ for all elements
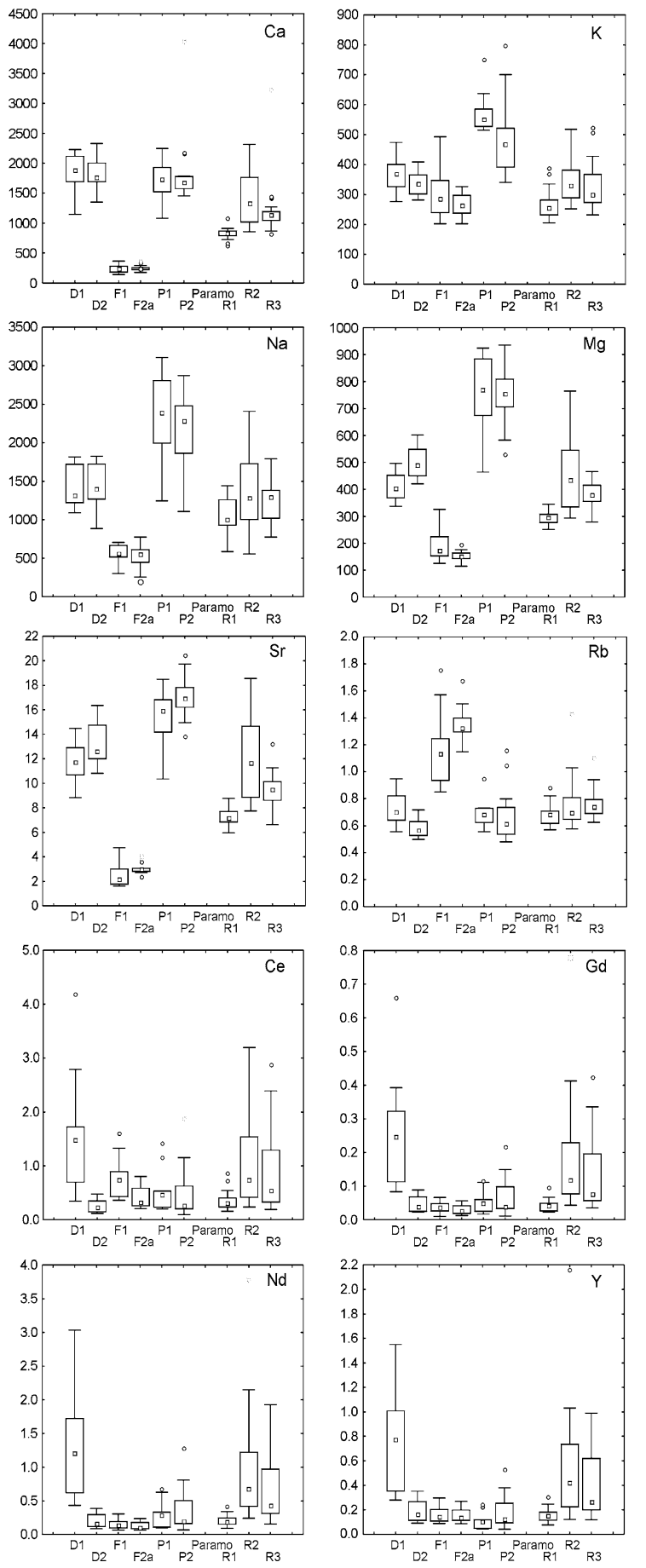
In Figs. 3 and 4 land uses are directly compared for a subset of ten parameters, all of which are later on used in the PCA. The box plots of the surface waters clearly reveal the distinction of concentrations for forested, disturbed, and pasture catchments. During both flow conditions, $\mathrm{Ca}^{2+}, \mathrm{Na}^{+}, \mathrm{Mg}^{2+}$, and $\mathrm{Sr}$ concentrations are lowest in forest streams. However, differences between disturbed and pasture streams for $\mathrm{Na}^{+}, \mathrm{Mg}^{2+}$, and $\mathrm{Sr}$ are noticeable during baseflow but not during fast flow, where variation is higher. For Rb, concentrations are clearly higher in forested streams during both flow conditions. Páramo water chemistry was only measured during baseflow and is low in all ten parameters. This is consistent with our assumption of a predominant input of ion-poor fog water (Bendix et al. 2004), although other factors, like depth to bed rock and diminished organic matter turnover, might play a role, too. High rare earth element (REE) concentrations during baseflow are observed only for D1. In general, low REE concentrations and low variation during baseflow contrasts with higher REE concentrations and high variation during fast flow condition for all sites. Variation in fast flow clearly is highest in D1, R2, and R3, though. More explanations for the patterns we observed between flow conditions and forested, pasture and disturbed catchments, respectively, are given in the discussion of the PCA analysis and PCA plots.

\subsection{Emerging Spatial Patterns at Baseflow (PCA)}

The projection of all investigated variables on two factors (principal components) accounted for almost $66 \%$ of the variation in the baseflow data (Fig. 5). All rare earth elements loaded negatively on principal factor 1 , meaning that they are all correlated among each other. Most of the other elements were grouped together with $\mathrm{pH}$ and EC, loading positively on principal component 2 and negatively on component 1 (Fig. 5). Rb plotted contrary to these elements.

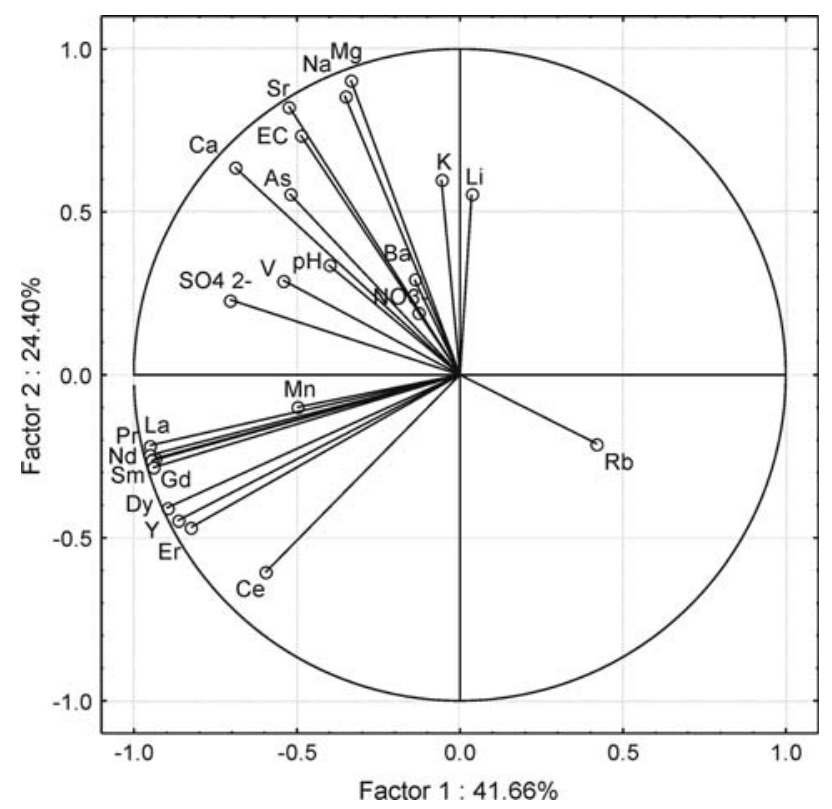

Fig. 5 Baseflow element loadings in the PCA for all elements (factors 1 and 2) 

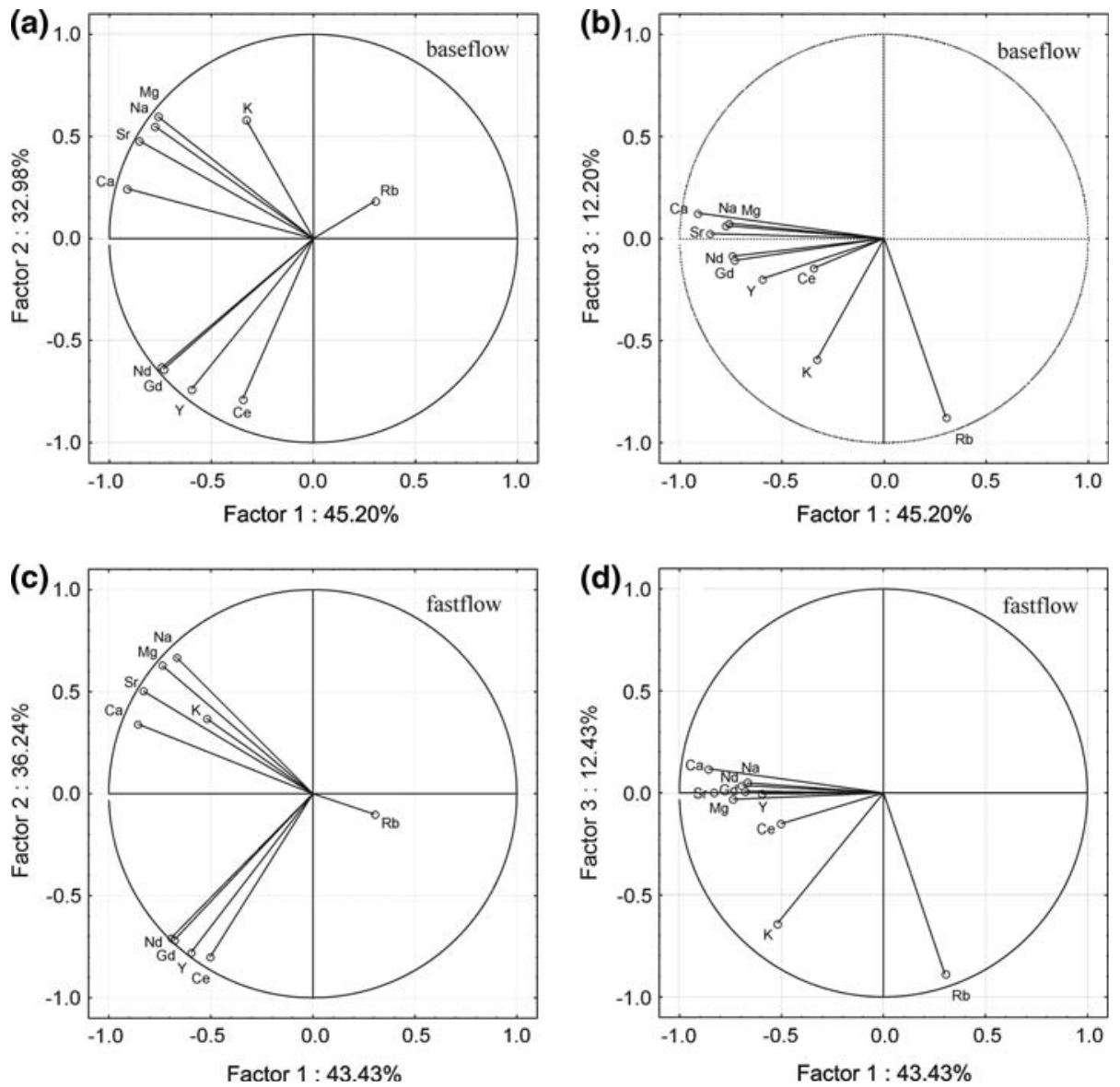

Fig. 6 Element loadings of selected parameters for baseflow (upper row) and fast flow samples (lower row). In the left-hand plots, factor 1 is projected against factor 2, the right-hand plots show factor 1 plotted against factor 3

For all further analyses, a subset was chosen (as explained in Sect. 2.3) consisting of $\mathrm{Ca}^{2+}, \mathrm{Ce}, \mathrm{Gd}, \mathrm{K}^{+}, \mathrm{Mg}^{2+}, \mathrm{Na}^{+}, \mathrm{Nd}, \mathrm{Rb}, \mathrm{Sr}$, and $\mathrm{Y}$ (Fig. 6). For baseflow, this subset explained $78 \%$ of the variation in the data with only two factors, with $\mathrm{Ca}^{2+}, \mathrm{Mg}^{2+}, \mathrm{Na}^{+}$, $\mathrm{Sr}$, and $\mathrm{K}$ grouping mostly along factor 1 (i.e., explaining the largest amount of variation) and the rare earth elements on factor 2 . The remaining element $\mathrm{Rb}$ showed a contrary loading compared to the other elements (see Fig. 6a).

The first two factors already accounted for $78 \%$ of variation in the data. Including the third component, this value increased to more than $90 \%$. Factor 3 was expressed exclusively by the occurrence of $\mathrm{Rb}$ and $\mathrm{K}^{+}$(see Fig. 6b), two elements with similar chemical properties and some interesting implications (see below, this section).

The ordination plot, including all baseflow samples according to station, revealed a distinct pattern of five groups plus one group of scattered data (see Fig. 7a). Group A contained the pasture creek samples (P1 and P2) and plotted negatively on factor 1 . Also on this axis, a second group (B) consisted of samples of a disturbed site (D2). Group C was arranged in the middle of the ordination plot and contained almost all river samples from 

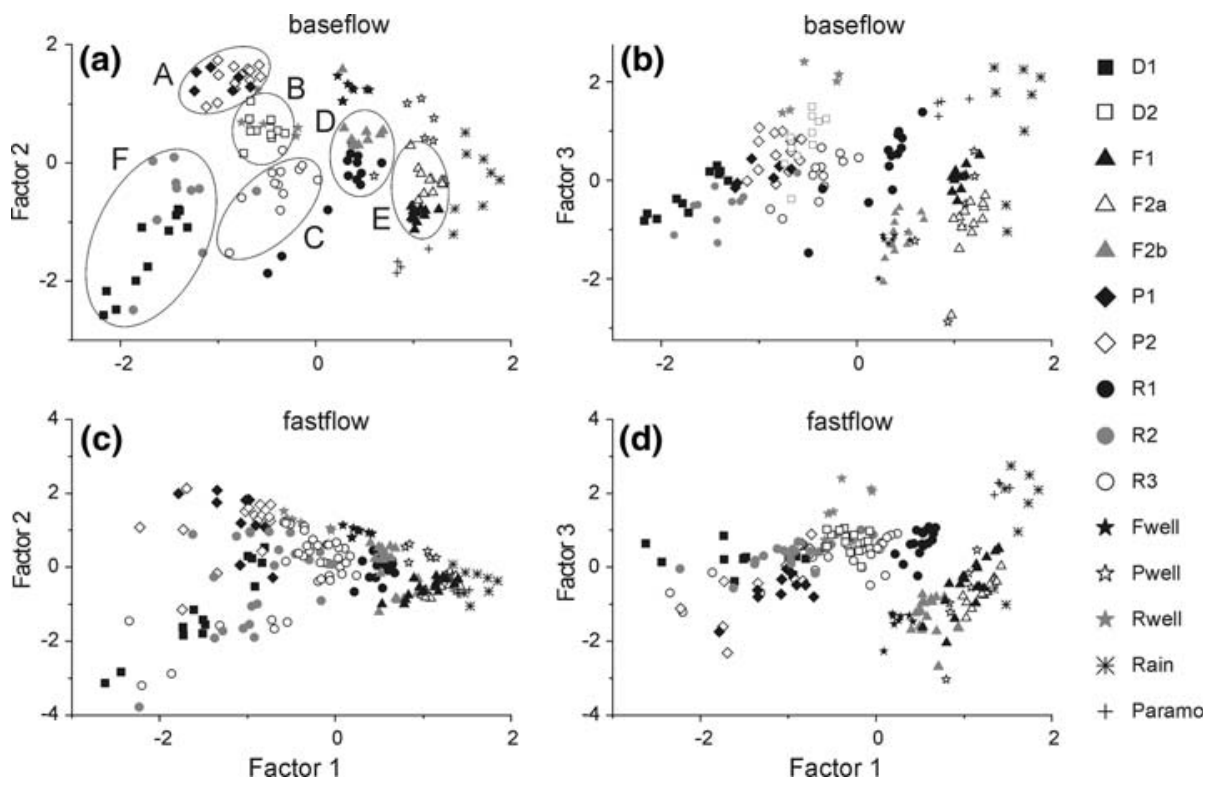

Fig. 7 Projections of sampling sites (ordination plots) for baseflow and fast flow samples. In plots (a) and (b) the baseflow samples are projected, first with factor 1 against factor 2 (a), and then with factor 1 against factor 3 (b). In plots (c) and (d), fast flow samples are projected, again first with factor 1 against factor 2 (c) and then with factor 1 against factor $3(\mathbf{d})$. Groups of stations with similar water chemistry are exemplarily encircled $(A-F)$ in plot (a)

the catchment outlet (R3). The uppermost main river samples (R1) plotted next to the F2b forest creek samples (group D). All F2b samples also plotted close to the water samples from the spring entering the same $\left(\mathrm{F}_{\text {well }}\right)$. The rest of the forest creek samples (F1, F2a) grouped tightly together (group E), with a positive loading on factor 1 and a slightly negative loading on factor 2. Close to this group, all Rain and Paramo samples as well as samples from the pasture spring $\left(\mathrm{P}_{\text {well }}\right)$ could be found. Lastly a sixth, much more diffuse group (F) included samples of the other disturbed (gravel excavation) site (D1) and most samples of the middle main river station (R2). This last group was the only one with a strong negative loading on both, factor 1 and 2. When plotting factor 1 against factor 3 in the ordination plot (Fig. 7b), the groupings remained relatively clear. Only sampling sites F2b and R1 (former group D) diverged.

The first component of the PCA, accounting for $45 \%$ of the variation in baseflow samples and linked to the elements $\mathrm{Ca}^{2+}, \mathrm{Mg}^{2+}, \mathrm{Na}^{+}$, and $\mathrm{Sr}$ most probably reflects changes in soil physical and chemical processes under different land-uses. It shows a clear trend for pasture creeks toward higher base cation concentrations. This is most likely attributable to the history of land conversion to pasture in this region (Biggs et al. 2002; Makeschin et al. 2008; Markewitz et al. 2001). Traditionally, forests are cut down and burned before grass turfs are planted on the freshly burned soil. If pastures become overgrown, burning is repeated or pastures are abandoned. The ashes resulting from repeated burning of pastures reduce soil acidity in the soil. As a consequence, concentrations of exchangeable $\mathrm{K}^{+}, \mathrm{Ca}^{2+}$, and $\mathrm{Mg}^{2+}$ have been found to be augmented in the uppermost layer $(0-10 \mathrm{~cm})$ compared to forest soil (Makeschin et al. 2008). Our aquatic data indicate that this increase of cations in the pastures upper soils is reflected in the water 
chemistry and constitutes the major component of water chemistry change. If we assume groundwater to be similar between sites these results suggest that near-surface flow is an important factor of influence for baseflow water chemistry in our catchment. High cation concentrations could not be due to groundwater influence because if this was the case, baseflow chemistry would be more similar among sites (see also Markewitz et al. 2001).

The second principal component distinguishes a component connected to rare earth element concentrations, attributable to a second type of land-use in our study area. Here, gravel excavation might be the cause for increased amounts of rare earth elements in stream water. According to Sholkovitz (1995) an increase in rare earth element concentration can be due to the weathering of parent rock. In weathering products rare earth elements are often accumulated (Patino et al. 2003; Price et al. 2005). The sampling station with a high gravel excavation activity (D1) was distinguished quite clearly by factor 2 . The middle main river station (R2) obviously was largely influenced by the water coming from D1, and therefore, also plotted close to this station in the PCA ordination. Another prominent characteristic of the D1 sub-catchment is its closeness to the only semi-paved road in the area. The road virtually follows the ridge of the D1 until it crosses the Andean depression at "El Tiro" at the western limit of our study catchment (see Fig. 1 and study site description for details). Large amounts of construction material (pebbles, stones, and cement) have been and still are transported into the catchment due to frequent construction works on the landslide affected road. Therefore, we hypothesize that the input of excavation and/or construction material leads to an increased washing out of rare earth elements, which is eventually reflected in the water chemistry. A geologic and/or a microclimatic explanation for an accumulation of rare earth elements might also be possible, but cannot be proven up to now. The only geologic map available for the study area does not convey differences in geology, which is also confirmed by a study of Makeschin et al. (2008). It cannot be ruled out though, that the north-western part of the area differs slightly in geological features and/or in weathering patterns. The predominantly easterly weather regime might, e.g., lead to a different micro-climate on the western slopes of the catchment. More detailed studies on geologic and climatic features in a small scale are needed to fill this gap.

Lastly, the third principal component is clearly associated with the occurrence of $\mathrm{Rb}$ and $\mathrm{K}^{+}$. As both elements also have a high loading on the first component, they seem to be partly influenced by soil physical/chemical processes. Showing the same loading on a third component though, they are an indicator of yet another reason for differences in water chemistry, which at least explains some $12 \%$ of the remaining variation. Our hypothesis is that the third component comprises a forest vegetation accumulation factor, leading to an increased level of $\mathrm{Rb}$ in the organic layer of forest creeks, which eventually enters the river. On pasture, vegetation biomass probably is too little, $\mathrm{pH}$ too high, or roots too shallow to increase concentrations notably. Nyholm and Tyler (2000) report a negative correlation between $\mathrm{Rb}$ uptake by plants and soil organisms and $\mathrm{K}^{+}$availability. According to Tyler (1997), acid soil conditions favor higher biological availability and therefore plant $\mathrm{Rb}$ uptake. Especially wood-decaying fungi may accumulate $\mathrm{Rb}$ according to favorable soil conditions (Tyler 1982). In growth experiments with Carex pilufera, Drobner and Tyler (1998) observed an excess uptake of Rb from acid soils, but ascribe this to secondary effects of soil acidity (e.g., leaching losses of $\mathrm{K}^{+}$, increased solubility of $\mathrm{Al}$ ), and not directly to $\mathrm{pH}$. Higher $\mathrm{Rb}$ concentrations in forest stream water might therefore be indirect biologic (vegetation accumulation) result of higher $\mathrm{Rb}$ availability in the acid soils of forest catchments. Our finding, that $\mathrm{Rb}$ concentration is higher and $\mathrm{K}^{+}$concentration lower in forest creeks and therefore probably also in the soil also leads to the assumption that forest 
trees have to adapt to low $\mathrm{K}^{+}$levels in the soil. This is confirmed by Soethe et al. (2008) who report foliar $\mathrm{K}^{+}$deficiency at 3,000 and 2,400 $\mathrm{m}$ under forested soils in our study area.

\subsection{Well Water Chemistry}

As mentioned in Sect. 2.2, the creek water of forest creek F2 is largely diverted into a channel, and only a fraction of this water continues on into direction of the sampling point F2b. This fraction mixes with spring water emerging from a rock fracture $\left(\mathrm{F}_{\text {well }}\right)$.

Our analysis revealed that the chemistry of $F_{\text {well }}$ was quite different from the creek water F2a, so the mixing resulted in a significant change of water chemistry at sampling point F2b. This mixing was reflected in the baseflow ordination plot (see Fig. 7a). Interestingly, well water sampled from the pasture sites $\left(\mathrm{P}_{\text {well }}\right)$ was chemically most similar to the forest creek samples (Fig. 7a), again indicating that geological differences among subcatchments are of minor importance for the observed differences in water chemistry. Compared to the other well waters $\left(\mathrm{F}_{\text {well }}, \mathrm{R}_{\mathrm{well}}\right) \mathrm{P}_{\text {well }}$ showed low concentrations of $\mathrm{Ca}^{2+}$, $\mathrm{Mg}^{2+}$, and $\mathrm{Na}^{+}$, slightly lower concentrations of $\mathrm{SiO}_{2}$ and similar concentrations of $\mathrm{K}^{+}$. $\mathrm{The} \mathrm{Na} /(\mathrm{Na}+\mathrm{Ca})$ ratio, which has been used as an indicator of cation inputs by weathering (ratio $\ll 1$ ) or precipitation (ratio approaching 1) (Markewitz et al. 2001) is 0.87 for $\mathrm{P}_{\text {well }}\left(0.72\right.$ for $\mathrm{F}_{\text {well }}, 0.76$ for $\left.\mathrm{R}_{\text {well }}\right)$. We therefore assume that $\mathrm{P}_{\text {well }}$ is fed by rain and fog water and probably runs as fast sub-surface flow through cracks in the rock, where it takes up some silicate. $\mathrm{R}_{\text {well }}$ and $\mathrm{F}_{\text {well }}$ are similar in their $\mathrm{Ca}^{2+}, \mathrm{Sr}, \mathrm{Mg}^{2+}, \mathrm{K}^{+}$, and $\mathrm{SiO}_{2}$ composition, but differ in $\mathrm{Na}^{+}$(with $\mathrm{R}_{\text {well }}$ having almost twice as much $\mathrm{Na}^{+}$). For the southern slope of the study catchment Wilcke et al. (2001) observed higher $\mathrm{Na}^{+}$concentrations in the A and B horizon compared to the organic layer. Conversely, $\mathrm{Mg}^{2+}$ and $\mathrm{Ca}^{2+}$ concentrations were found to notably decrease. Thus, it seems clear, that $\mathrm{R}_{\text {well }}$ and $\mathrm{F}_{\text {well }}$ are both groundwater-like subsurface flows, with $\mathrm{R}_{\text {well }}$ probably having longer residence times as observed by the enrichment of $\mathrm{Na}^{+}$. The closeness of $\mathrm{D} 2$ to $\mathrm{R}_{\text {well }}$ in Fig. $7 \mathrm{a}$ might hint to a higher contribution of groundwater sources for this stream. Further analysis such as ${ }^{2} \mathrm{H}$ and ${ }^{18} \mathrm{O}$ isotope based estimations of water mean transit times should be conducted to further explain these observations.

Our first hypothesis that the analysis of hydro-chemical characteristics of surface and subsurface flows can help to elucidate sources and flow-paths of water is in agreement with our study. We also conclude, that the differences in water chemistry are the consequence of land-use practices, and are not due to differences in geological features (second hypothesis).

\subsection{Emerging Spatial Patterns at Fast Flow (PCA)}

Compared to baseflow, the fast flow projection of factors 1 and 2 was almost identical in respect to the relation of the variables to each other and their loadings, respectively (compare Fig. 6a, c). $\mathrm{Ca}^{2+}, \mathrm{K}^{+}, \mathrm{Mg}^{2+}, \mathrm{Na}^{+}$, and $\mathrm{Sr}$ were still only associated with factor 1 , the rare earth elements on factor 2 . $\mathrm{Rb}$ and $\mathrm{K}^{+}$again were loading on factor 3 and showed opposite loadings on factor 1 (compare Fig. 6b, c). In general, the principal components 1 and 2 explained $80 \%$ of the variation in fast flow data (Table 4); principal component 3 explained an additional $12 \%$ of the variation.

The ordination plot of the fast flow data (Fig. 7c) revealed a slightly more compressed pattern compared to the baseflow samples (Fig. 7a). Only forest (F1, F2a) and pasture (P1, P2) creeks, equivalent to groups A and E still separated relatively clearly from the other 
Table 4 Eigenvalues of and percent variability explained by the PCA factors

\begin{tabular}{lllll}
\hline Factor & Eigenvalue & \% Total & Cumulative & \% Cumulative \\
\hline Baseflow & & & & \\
1 & 4.52 & 45.20 & 4.52 & 45.20 \\
2 & 3.29 & 32.98 & 7.81 & 78.18 \\
3 & 1.22 & 12.20 & 9.04 & 90.38 \\
Fast flow & & & & \\
1 & 4.34 & 43.42 & 4.48 & 43.42 \\
2 & 3.63 & 36.24 & 7.97 & 79.67 \\
3 & 1.24 & 12.43 & 9.21 & 92.10 \\
\hline
\end{tabular}

Table 5 Comparison of mean concentrations of selected parameters in tropical streams

\begin{tabular}{llllll}
\hline Parameter & $\begin{array}{l}\text { McDowell and } \\
\text { Asbury (1994) } \\
\text { mg/l }\end{array}$ & $\begin{array}{l}\text { Newbold et al. } \\
(1995) \\
\text { mg/l (FWM) }\end{array}$ & $\begin{array}{l}\text { Ramos-Escobedo and } \\
\text { Vázquez (2001) } \\
\text { mg/l }\end{array}$ & $\begin{array}{l}\text { Neill et al. } \\
(2001) \\
\text { mg/l }\end{array}$ & $\begin{array}{l}\text { Our study (all } \\
\text { samples) } \\
\text { mg/l }\end{array}$ \\
\hline $\mathrm{Ca}^{2+}$ & $2.22-6.27$ & $4.90-10.99$ & $6.30-14.30$ & - & $0.20-2.15$ \\
$\mathrm{Cl}^{-}$ & $6.24-8.82$ & - & $2.80-23.70$ & - & $0.77-0.85$ \\
$\mathrm{~K}^{+}$ & $0.22-0.51$ & $0.70-2.46$ & $0.30-5.30$ & - & $0.27-0.52$ \\
$\mathrm{Mg}^{2+}$ & $1.20-4.42$ & $1.84-4.20$ & $4.10-9.90$ & - & $0.14-0.69$ \\
$\mathrm{Na}^{+}$ & $4.36-7.52$ & $3.56-7.94$ & $10.80-21.40$ & - & $0.54-2.36$ \\
$\mathrm{NO}_{3}{ }^{-}$ & $0.24-0.29$ & $0.51-1.23$ & $2.10-3.00$ & $0.05-0.68$ & $0.72-1.11$ \\
$\mathrm{SO}_{4}{ }^{2-}$ & $2.24-2.67$ & - & $0.10-1.60$ & - & $0.59-1.37$ \\
\hline
\end{tabular}

Table 6 Comparison of base- to fast flow concentrations for the ten elements used in PCA

\begin{tabular}{|c|c|c|c|c|c|c|c|c|c|c|}
\hline & $\mathrm{Na}^{+}$ & $\mathrm{Ca}^{2+}$ & $\mathrm{Mg}^{2+}$ & $\mathrm{K}^{+}$ & $\mathrm{Sr}$ & $\mathrm{Rb}$ & $\mathrm{Y}$ & $\mathrm{Ce}$ & $\mathrm{Nd}$ & $\mathrm{Gd}$ \\
\hline D1 & - & - & - & - & - & $\uparrow$ & $\uparrow$ & $\uparrow$ & $\uparrow$ & $\uparrow$ \\
\hline D2 & $\downarrow$ & - & $\downarrow$ & - & $\downarrow$ & $\uparrow$ & $\uparrow$ & $\uparrow$ & $\uparrow$ & $\uparrow$ \\
\hline $\mathrm{F} 1$ & $\downarrow$ & $\uparrow$ & $\uparrow$ & $\uparrow$ & $\uparrow$ & $\uparrow$ & $\uparrow$ & $\uparrow$ & $\uparrow$ & $\uparrow$ \\
\hline $\mathrm{F} 2 \mathrm{a}$ & $\downarrow$ & - & - & - & - & - & $\uparrow$ & $\uparrow$ & $\uparrow$ & $\uparrow$ \\
\hline $\mathrm{F} 2 \mathrm{~b}$ & $\downarrow$ & $\downarrow$ & $\downarrow$ & - & $\downarrow$ & - & $\uparrow$ & $\uparrow$ & $\uparrow$ & $\uparrow$ \\
\hline $\mathrm{P} 1$ & - & - & - & $\uparrow$ & - & - & - & $\uparrow$ & $\uparrow$ & $\uparrow$ \\
\hline $\mathrm{P} 2$ & $\downarrow$ & - & - & - & - & - & $\uparrow$ & $\uparrow$ & $\uparrow$ & $\uparrow$ \\
\hline R1 & $\downarrow$ & - & - & - & - & - & $\uparrow$ & - & - & $\uparrow$ \\
\hline R2 & $\downarrow$ & $\downarrow$ & $\downarrow$ & - & - & - & - & - & - & - \\
\hline R3 & $\downarrow$ & - & - & - & - & - & $\uparrow$ & $\uparrow$ & $\uparrow$ & $\uparrow$ \\
\hline
\end{tabular}

Arrows indicate significant concentration change $(\uparrow$ means higher concentration in fast flow, and $\downarrow$ means lower concentration in fast flow, "-" indicates that no significant change was observed). Cells with a regular pattern in more than three stations are shaded in gray

groups. However, former groups $\mathrm{B}, \mathrm{C}, \mathrm{D}$, and $\mathrm{F}$ were mixing more or less strongly. In general, factor 1 decreased in importance during fast flow, whereas factor 2 increased (see Table 4). Factor 1 therefore, seems to be rather associated with baseflow than with fast flow conditions. 
Relative changes in mean element concentration between base- and fast flow condition are summarized in Table 6 and reveal some general patterns. For all sites, $\mathrm{Na}^{+}$concentrations significantly decreased during fast flow compared to baseflow condition, which can be attributed to the mixing of stream water with less concentrated water such as rainfall (dilution pattern). However, Boy et al. (2008) also report low $\mathrm{Na}^{+}$concentrations in soil water of 15 and $30 \mathrm{~cm}$ depth $(\sim 0.5 \mathrm{mg} / \mathrm{l})$ compared to stream water $(\sim 3 \mathrm{mg} / \mathrm{l})$ for forest soils and microcatchments in our study area. A dilution effect could therefore also occur through the mixing of stream water with soil water during events. In contrast to $\mathrm{Na}^{+}$, rare earth element (REE) concentrations increased significantly during fast flows (flushing pattern). As mentioned earlier, REEs are mostly associated with weathering products, and therefore should be higher in soil layers containing weathered material, as for example occurring in the A horizon (below the organic layer). Measurements of soil water from the southern, forested slope of the San Francisco catchment indicate that REE concentrations are higher in $30 \mathrm{~cm}$ soil depth compared to $15 \mathrm{~cm}$ soil depth (unpublished data). REE concentration in rain, on the other hand, was at least an order of magnitude lower than stream water concentration in our data. Thus, both changes in fast flow concentration $\left(\mathrm{Na}^{+}\right.$decrease and REE increase) can be explained by storm flow being created by a flushing of soil water from around $30 \mathrm{~cm}$ depth, at least for the forested sub-catchments. For pasture sites, measurements of soil water concentration of $\mathrm{Na}^{+}$and REE are still missing, so no general conclusions can be made here.

According to our third hypothesis, stream waters should be completely mixed in the fast flow ordination plot. This was not the case. However, there was some mixing in the plot, and the formerly clearly separated groups partly converged. Rain events therefore were not capable of completely masking the chemical fingerprint of the subcatchments. This might be due to our finding of a flushing of soil water during fast flow events. The fact that ion ratios are rather influenced by geographical location than by stage of stream flow has also been reported by McNeil et al. (2005) for mesoscale catchments in Queensland, Australia. It was also established, that rare earth elements are important tracers in clear headwater streams, as they are capable of conveying weathering patterns and water source areas (Chung et al. 2008; Picouet et al. 2002; Velbel and Price 2007). This confirms our fourth hypothesis, that standard parameters like $\mathrm{pH}, \mathrm{EC}, \mathrm{SO}_{4}{ }^{2-}$, or $\mathrm{Ca}^{2+}$ are not sufficient to explain controls on water chemistry in clear mountain streams.

\section{Conclusion}

Studies investigating alterations in soil processes of tropical montane forests after land-use change are relatively abundant (Bautista-Cruz and del Castillo 2005; Jin et al. 2000; Rhoades et al. 2000), but the influence of these changes on the water chemistry has mostly been neglected. Here we investigated differences in water element composition in closely related tributaries with the objective of defining the main controls on water chemistry at a catchment scale.

We conclude that principal component analysis indeed is effective in assisting in the evaluation of spatial surveys of water chemistry change, even if concentrations of nutrients and elements are low. The inclusion of over 30 elements permitted us to identify those with the highest potential to explain predominant catchment processes. Standard parameters like $\mathrm{pH}$ and conductivity did not enable us to differentiate between sampling stations in detail. However, rare earth element (REE) concentrations clearly separated another sampling station, highlighting gravel excavation as a second important anthropogenic process 
influencing water chemistry in our catchment. Rare earth elements, which have been extensively used as tracers for chemical weathering also gave insights into storm flow origin. Our finding, that $\mathrm{Rb}$ concentration was higher and $\mathrm{K}^{+}$concentration lower in forest creeks support the results of other studies, that forest trees have to adapt to low $\mathrm{K}^{+}$levels in the soil.

The inclusion of well water from the F2 sub-catchment could explain at least some of the differences between F2b and the other forest-stream stations (F1, F2a). We could also observe a decoupling of fast and slow subsurface flow paths by analyzing the three well waters. This result highlights the importance of sampling springs and seeps in mountain catchments, as also claimed by Soulsby et al. (2007).

Our central finding is that in cloud forest catchments land-use practices not only influence soil characteristics but also change water chemistry through various ways. Due to the extreme low nutrient and element concentrations in the streams, even small contributions of ion-rich water (e.g., well water) can already change the overall water quality of streams. This high sensitivity of cloud forest catchments certainly has implications for land-use and water quality management.

Our next step will be to calculate nutrient budgets for pasture and forested sub-catchments, and to more closely scrutinize changes in flow paths between pasture and forest creeks using isotopic tracers and end member mixing analysis (EMMA). In the end, this information will be used to evaluate the performance of hydro-biogeochemical catchment models.

In general, more studies on tropical headwater catchments are needed to be able to compare our results and to develop a more general process understanding of the ever more threatened cloud forest ecosystems.

Acknowledgments We are indebted to the Deutsche Forschungsgemeinschaft (DFG) for funding this project (FOR816). We thank Nature and Culture International (NCI) in Loja for providing research facilities and access to the area. Furthermore, we thank Dr. Jan Feyen for initiating and supporting the cooperation between the University of Giessen, Germany and PROMAS in Ecuador. The help of Beate Lindenstruth, Heike Weller, and Dorit Zörner with the IC and ICP measurements is greatly appreciated.

\section{References}

Albrecht A, Schultze U, Bugallo PB, Wydler H, Frossard E, Fluhler H (2003) Behavior of a surface applied radionuclide and a dye tracer in structured and repacked soil monoliths. J Environ Radioact 68(1):47-64

Ataroff V, Rada F (2000) Deforestation impact on water dynamics in a Venezuelan Andean cloud forest. Ambio 29(7):440-444

Bautista-Cruz A, del Castillo RF (2005) Soil changes during secondary succession in a tropical montane cloud forest area. Soil Sci Soc Am 69:906-914

Beck E, Makeschin F, Haubrich F, Richter M, Bendix J, Valarezo C (2008) The ecosystem (Reserva Biológica San Francisco). In: Beck E, Bendix J, Kottke I, Makeschin F, Mosandl R (eds) Gradients in a tropical mountain ecosystem of Ecuador. Ecological Studies. Springer Verlag

Bendix J, Fabian P, Rollenbeck R (2004) Gradients of fog and rain in a tropical montane cloud forest of southern Ecuador and its chemical composition. In: Conference proceeding, pp 11-15

Bendix J, Rollenbeck R, Richter M, Fabian P, Emck P (2008) Climate. In: Beck E, Bendix J, Kottke I, Makeschin F, Mosandl R (eds) Gradients in a tropical mountain ecosystem of Ecuador. Ecological Studies. Springer Verlag

Bernal S, Sabater F (2008) The role of lithology, catchment size and the alluvial zone on the hydrogeochemistry of two intermittent Mediterranean streams. Hydrol Process 22(10):1407-1418

Biggs TW, Dunne T, Domingues TF, Martinelli LA (2002) Relative influence of natural watershed properties and human disturbance on stream solute concentrations in the southwestern Brazilian Amazon basin. Water Resour Res 38(8):1150 
Boy J, Wilcke W (2008) Tropical Andean forest derives calcium and magnesium from Saharan dust. Global Biogeochem Cycles 22(1):1-11

Boy J, Valarezo C, Wilcke W (2008) Water flow paths in soil control element exports in an Andean tropical montane forest. Eur J Soil Sci 59(6):1209-1227

Burt TP, Pinay G (2005) Linking hydrology and biogeochemistry in complex landscapes. Prog Phys Geog 29(3):297-316

Bwire Ojiambo S, Berry Lyons W, Welch KA, Poreda RJ, Johannesson KH (2003) Strontium isotopes and rare earth elements as tracers of groundwater-lake water interactions, Lake Naivasha, Kenya. Appl Geochem 18(11):1789-1805

Chapman T (1991) Comment on 'Evaluation of automated techniques for base flow and recession analyses' by R.J. Nathan and T.A. McMahon. Water Resour Res 27(7):1783-1784

Christophersen N, Hooper RP (1992) Multivariate analysis of stream water chemical data: the use of principal component analysis for the end-member mixing problem. Water Resour Res 28(1):99-107

Chung CH, You CF, Chu HY (2008) Weathering sources in the Gaoping (Kaoping) river catchments, southwestern Taiwan: insights from major elements, Sr isotopes, and rare earth elements. J Mar Sys 76(4):433-443

Clow DW, Mast MA, Campbell DH (1996) Controls on surface water chemistry in the upper Merced River basin, Yosemite National Park, California. Hydrol Process 10(5):727-746

Doumenge C, Gilmour DA, Ruiz Perez M, Blockhus J (1995) Tropical montane cloud forests: conservation status and management issues. In: Hamilton LS, Juvik JO, Scatena FN (eds) Tropical Montane cloud forests. Ecol Stud 110:24-37. Springer Verlag, New York

Drobner U, Tyler G (1998) Conditions controlling relative uptake of potassium and rubidium by plants from soils. Plant Soil 201(2):285-293

Elsenbeer H, Lack A (1996) Hydrometric and hydrochemical evidence for fast flowpaths at La Cuenca, western Amazonia. J Hydrol 180(1-4):237-250

Elsenbeer H, Vertessy RA (2000) Stormflow generation and flowpath characteristics in an Amazonian rainforest catchment. Hydrol Process 14(14):2367-2381

Elsenbeer H, West A, Bonell M (1994) Hydrologic pathways and stormflow hydrochemistry at south creek, Northeast Queensland. J Hydrol 162(1-2):1-21

Feddema JJ, Oleson KW, Bonan GB, Mearns LO, Buja LE, Meehl GA, Washington WM (2005) The importance of land-cover change in simulating future climates. Science 210:1674-1678

Goller R, Wilcke W, Leng MJ, Tobschall HJ, Wagner K, Valarezo C, Zech W (2005) Tracing water paths through small catchments under a tropical montane rain forest in south Ecuador by an oxygen isotope approach. J Hydrol 308(1-4):67-80

Günther S, Weber M, Erreis R, Aguirre N (2007) Influence of distance to forest edges on natural regeneration of abandoned pastures: a case study in the tropical mountain rain forest of Southern Ecuador. Eur J Forest Res 126:67-75

Hannigan RE, Sholkovitz ER (2001) The development of middle rare earth element enrichments in freshwaters: weathering of phosphate minerals. Chem Geol 175(3-4):495-508

Homeier J, Dalitz H, Breckle S-W (2002) Waldstruktur und Baumartendiversität im montanen Regenwald der Estacón Cientíca San Franscisco in Südecuador. Ber d Reinh Tüxen-Ges 14:109-118

Hooper RP (2003) Diagnostic tools for mixing models of stream water chemistry. Water Resour Res 39(3): $1-11$

Hu Z, Haneklaus S, Sparovek G, Schnug E (2006) Rare earth elements in soils. Commun Soil Sci Plant Anal 37(9):1381-1420

Huwe B, Zimmermann B, Zeilinger J, Quizhpe M, Elsenbeer H (2008) Gradients and patterns of soil physical parameters at local, field and catchment scales. In: Beck E, Bendix J, Kottke I, Makeschin F, Mosandl R (eds) Gradients in a tropical mountain ecosystem of Ecuador. Ecological Studies. Springer Verlag

Jin VL, West LT, Haines BL, Peterson CJ (2000) P retention in tropical pre-montane soils across forestpasture interfaces. Soil Sci 165(11):881-889

Litherland M, Aspden JA, Jemielita RA (1994) The metamorphic belts of Ecuador. Br Geol Surv Overseas Memoir 11:1-147

Makeschin F, Haubrich F, Abiy M, Burneo JI, Klinger T (2008) Pasture management and natural soil regeneration. In: Beck E, Bendix J, Kottke I, Makeschin F, Mosandl R (eds) Gradients in a tropical mountain ecosystem of Ecuador. Ecological Studies. Springer Verlag

Markewitz D, Davidson EA, Figueiredo RO, Victoria RL, Krusche AV (2001) Control of cation concentrations in stream waters by surface soil processes in an Amazonian watershed. Nature 410(6830):802-805

McDowell W, Asbury CE (1994) Export of carbon, nitrogen, and major ions from 3 tropical Montane watersheds. Limnol Oceanogr 39(1):111-125 
McLeod M, Schnipper LA, Taylor MD (1998) Preferential flow in a well drained and a poorly drained soil under different overhead irrigation regimes. Soil Use Manage 14(2):96-100

McNeil VH, Cox ME, Preda M (2005) Assessment of chemical water types and their spatial variation using multi-stage cluster analysis, Queensland, Australia. J Hydrol 310(1-4):181-200

Neill C, Deegan LA, Thomas SM, Cerri CC (2001) Deforestation for pasture alters nitrogen and phosphorus in small Amazonian Streams. Ecol Appl 11(6):1817-1828

Neill C, Elsenbeer H, Krusche AV, Lehmann J, Markewitz D, Figueiredo RD (2006) Hydrological and biogeochemical processes in a changing Amazon: results from small watershed studies and the largescale biosphere-atmosphere experiment. Hydrol Process 20(12):2467-2476

Newbold JD, Sweeney BW, Jackson JK, Kaplan LA (1995) Concentrations and export of solutes from 6 mountain streams in Northwestern Costa-Rica. J North Am Benthol Soc 14(1):21-37

Nyholm NEI, Tyler G (2000) Rubidium content of plants, fungi and animals closely reflects potassium and acidity conditions of forest soils. For Ecol Manage 134(1-3):89-96

Patino LC, Velbel MA, Price JR, Wade JA (2003) Trace element mobility during spheroidal weathering of basalts and andesites in Hawaii and Guatemala. Chem Geol 202(3-4):343-364

Picouet C, Duprq B, Orange D, Valladon M (2002) Major and trace element geochemistry in the upper Niger river (Mali): physical and chemical weathering rates and CO2 consumption. Chem Geol 185(12):93-124

Poor CJ, McDonnell JJ (2007) The effects of land use on stream nitrate dynamics. J Hydrol 332(1-2):54-68

Price JR, Velbel MA, Patino LC (2005) Allanite and epidote weathering at the Coweeta Hydrologic Laboratory, western North Carolina, USA. Am Miner 90:101-114

Ramos-Escobedo MG, Vázquez G (2001) Major ions, nutrients and primary productivity in volcanic neotropical streams draining rainforest and pasture catchments at Los Tuxtlas, Veracruz, Mexico. Hydrobiologia 445(1-3):67-76

Rhoades CC, Eckert GE, Coleman DC (2000) Soil carbon differences among forest, agriculture, and secondary vegetation in lower Montane Ecuador. Ecol Appl 10(2):497-505

Rice KC, Hornberger GM (1998) Comparison of hydrochemical tracers to estimate source contributions to peak flow in a small, forested, headwater catchment. Water Resour Res 34(7):1755-1766

Rodgers P, Soulsby C, Waldron S, Tetzlaff D (2005) Using stable isotope tracers to assess hydrological flow paths, residence times and landscape influences in a nested mesoscale catchment. Hydrol Earth Syst Sci 9(3):139-155

Rollenbeck R (2006) Variability of precipitation in the Reserva Biólogica San Francisco/Southern Ecuador. Lyonia 9(1):43-51

Schellekens J, Scatena FN, Bruijnzeel LA, van Dijk AIJM, Groen MMA, van Hogezand RJP (2004) Stormflow generation in a small rainforest catchment in the luquillo experimental forest, Puerto Rico. Hydrol Process 18(3):505-530

Sholkovitz ER (1995) The aquatic chemistry of rare earth elements in rivers and estuaries. Aquat Geochem $1: 1-34$

Simeonov V, Stratis JA, Samara C, Zachariadis G, Voutsa D, Anthemidis A, Sofoniou M, Kouimtzis T (2003) Assessment of the surface water quality in Northern Greece. Water Res 37(17):4119-4124

Soethe N, Wilcke W, Homeier J, Lehmann J, Engels C (2008) Plant growth along the altitudinal gradientrole of plant nutritional status, fine root activity, and soil properties. In: Beck E, Bendix J, Kottke I, Makeschin F, Mosandl R (eds) Gradients in a tropical mountain ecosystem of Ecuador. Ecological Studies

Soulsby C, Tetzlaff D, Rodgers P, Dunn S, Waldron S (2006) Runoff processes, stream water residence times and controlling landscape characteristics in a mesoscale catchment: An initial evaluation. J Hydrol 325(1-4):197-221

Soulsby C, Tetzlaff D, van den Bedem N, Malcolm IA, Bacon PJ, Youngson AF (2007) Inferring groundwater influences on surface water in montane catchments from hydrochemical surveys of springs and streamwaters. J Hydrol 333(2-4):199-213

Tetzlaff D, Soulsby C (2007a) Conceptualization of runoff processes using a geographical information system and tracers in a nested mesoscale catchment. Hydrol Process 21(10):1289-1307

Tetzlaff D, Soulsby C (2007b) Connectivity between landscapes and riverscapes-a unifying theme in integrating hydrology and ecology in catchment science? Hydrol Process 21(10):1385-1389

Tyler G (1982) Metal accumulation by wood-decaying fungi. Chemosphere 11(11):1141-1146

Tyler G (1997) Influence of acidity and potassium saturation on plant uptake of indigenous soil rubidium. Environ Exp Bot 38(2):181-186

Uhlenbrook S, Frey M, Leibundgut C, Maloszewski P (2002) Hydrograph separations in a mesoscale mountainous basin at event and seasonal timescales. Water Resour Res 38(6):1-14 
Vanderborght J, Gahwiller P, Fluhler H (2002) Identification of transport processes in soil cores using fluorescent tracers. Soil Sci Soc Am J 66(3):774-787

Velbel MA, Price JR (2007) Solute geochemical mass-balances and mineral weathering rates in small watersheds: methodology, recent advances, and future directions. Appl Geochem 22(8):1682-1700

Viers J, Wasserburg GJ (2004) Behavior of Sm and Nd in a lateritic soil profile. Geochim Cosmochim Acta 68(9):2043-2054

Werner F, Homeier J, Gradstein R (2005) Diversity of vascular epiphytes on isolated remnant trees in the montane forest belt of Southern Ecuador. Ecotropica 11:21-40

Wilcke W, Yasin S, Valarezo C, Zech W (2001) Change in water quality during the passage through a tropical montane rain forest in Ecuador. Biogeochemistry 55(1):45-72

Wilcke W, Yasin S, Schmitt C, Valarezo C, Zech W (2008) Soils along the altitudinal transect and in catchments. In: Beck E, Bendix J, Kottke I, Makeschin F, Mosandl R (eds) Gradients in a tropical mountain ecosystem of Ecuador. Ecological Studies. Springer Verlag

Willems P (2009) A time series tool to support the multi-criteria performance evaluation of rainfall-runoff models. Environ Model Software 24(3):311-321

Worrall F, Swank WT, Burt TP (2003) Changes in stream nitrate concentrations due to land management practices, ecological succession, and climate: developing a systems approach to integrated catchment response. Water Resources Research 39(7):1-14 